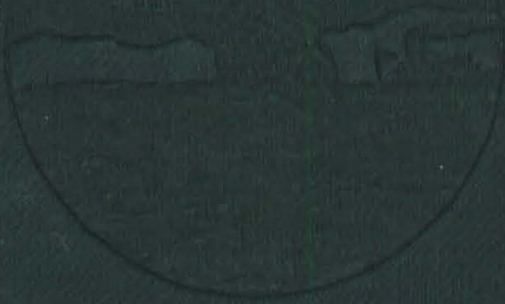

$=$ 

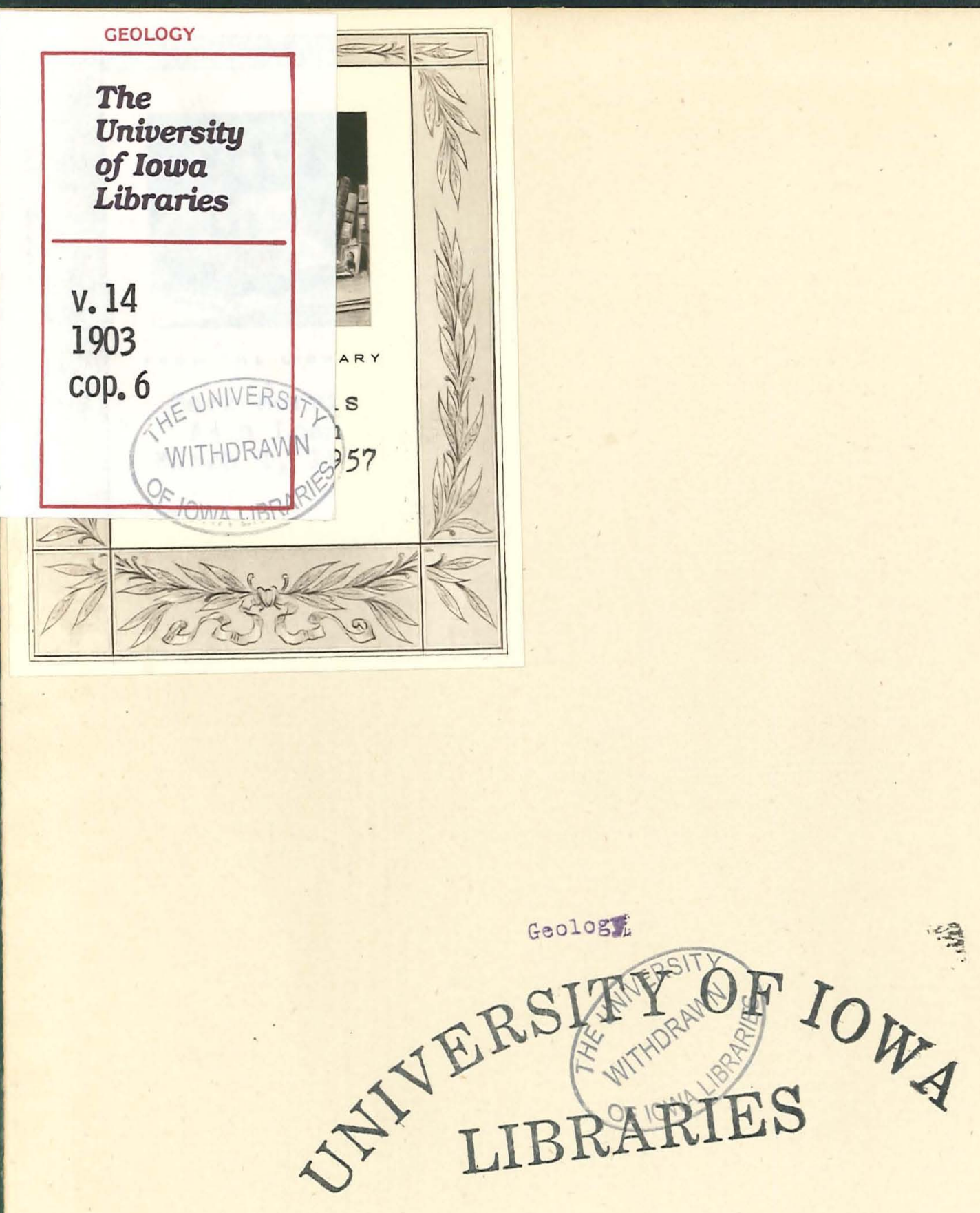


\section{IOWA .}

\section{GEOLOGICAL SURVEY,}

VOLUME XIV

\section{ANNUAL REPORT, 1903 \\ WITH}

ACCOMPANYING PAPERS

samuel calvin. A. M., Ph.D., State geologist

T. E. SAVAge, assistant State Geologist

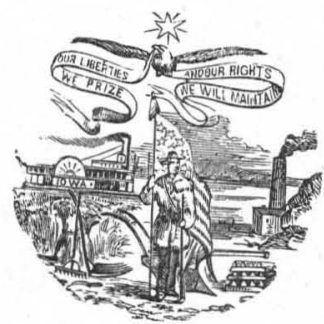

DES MOINES

Published for Iowa Geological Survey 1904 
DES MOINES:

BERNARD MURPHY, STATE PRINTER

1904 


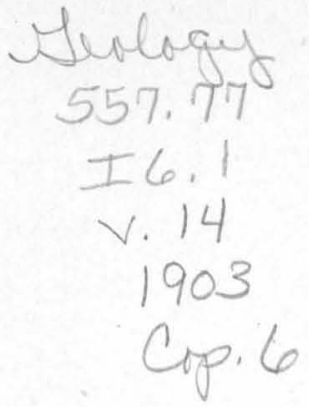

\section{GEOLOGICAL BOARD.}

His Excellency, A. B. Cummins ...... Governor of Iowa Hon. B. F. Carroll ............ Auditor of State Dr. Geo. E. Maclean ... Pres. State University of Iowa Dr. A. B. Storms . . . . . . . Pres. Iowa State College Prof. B. Shimek ..... Pres. Iowa Academy of Sciences 
GEOLOGICAL CORPS

Samuel Calvin. State Geologist

T. E. SAVAGE Assistant State Geologist

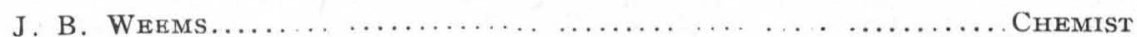

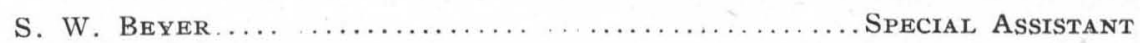

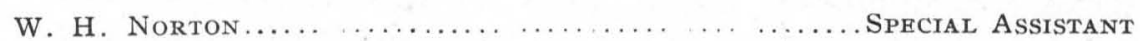

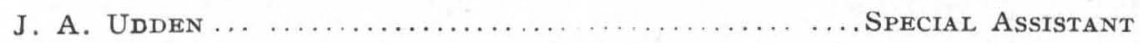

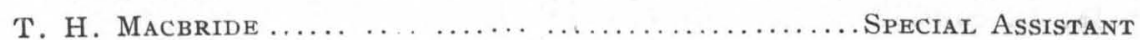

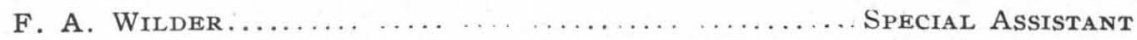

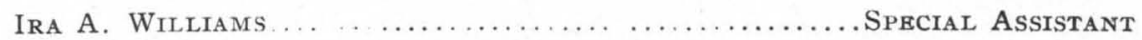

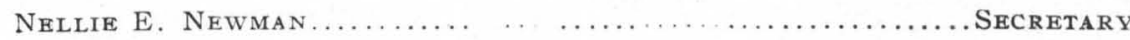




\section{CONTENTS.}

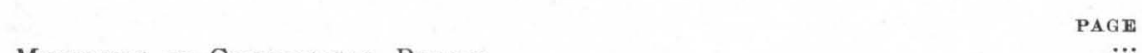

Members of Geological BoArd $\ldots \ldots \ldots \ldots \ldots \ldots \ldots \ldots \ldots \ldots \ldots \ldots \ldots \ldots \ldots \ldots$

Geological Corps $\ldots \ldots \ldots \ldots \ldots \ldots \ldots \ldots \ldots \ldots \ldots \ldots \ldots \ldots \ldots \ldots \ldots$ iv

TaBle of Contents $\ldots \ldots \ldots \ldots \ldots \ldots \ldots \ldots \ldots \ldots \ldots \ldots \ldots \ldots \ldots \ldots \ldots \ldots$

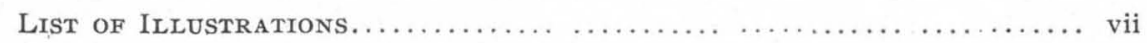

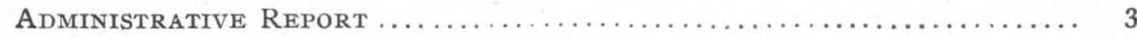

Statistics of Mineral Production $\ldots \ldots \ldots \ldots \ldots \ldots \ldots \ldots \ldots$

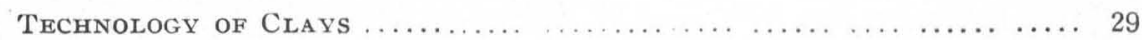

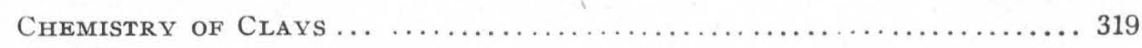

Selection, Installation and Care of Power Plants............. 347

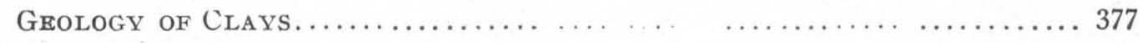

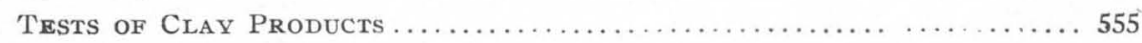

Directory of Clay Workers . . . . . . . . . . . . . . . . . . . . 621

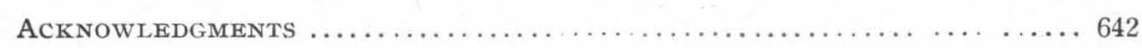

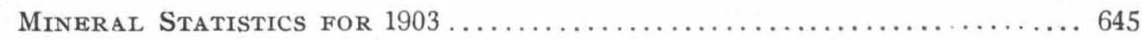





\section{LIST OF ILLUSTRATIONS.}

Plates.

I. Map showing progress of detailed mapping.

II. Geological map of Iowa.

III. Map of the drift sheets of Iowa.

IV. Standard nine-foot dry pan with steel frame.

V. Vertical type of soft mud brick machine.

VI. Vertical type of mold brick machine.

VII. Type of the automatic rotary side cutter. Horizontal type of stiff mud brick machine and automatic sander.

VIII. Automatic oscillating reciprocal down cut table.

IX. The Richardson repress. Front and back views.

$\mathrm{X}$. The Eagle double die brick repress. Front view.

XI. Domeless boiler with nozzles, shell extended.

XII. Method of hanging a shell boiler.

XIII. Setting for one 72-inch horizontal tubular boiler with oven furnace.

XIV. Setting for one 72 :inch horizontal tubular boiler.

XV. Type of simple, direct acting boiler feed pump, in section.

XVI. Shale pit of Mason City Brick and Tile Company, Mason City, Iuwa.

XVII. Plant of the Mason City Brick and Tile Company.

XVIII. Pit of the Granite Brick Company.

XIX. Pit of the Centerville Brick and Tile Company.

$X X$. Pit of the Boone Brick and Tile Company.

XXI. Section on Gray creek, Pleasant township, Monroe county.

XXII. Section of the upper Coal Measures, Stennett, Montgomery county.

XXIII. Present pit of the Flint Brick Company, Des Moines, Iowa.

XXIV. Plant of the Flint Brick Company, Des Moines, Iowa.

$X X V$. A modern rotary cutting table used by the Iowa Brick Company, Des Moines, Iowa.

XXVI. Plant of the Des Moines Brick and Tile Company, Des Moines, Iowa.

XXVII. A portion of the plant of the Ottumwa Brick and Construction Company, Ottumwa, Iowa.

XXVIII. Pit of the Lehigh Brick and Tile Company, Lehigh, Iowa.

XXIX. Plant of the Lehigh Brick and Tile Company, Lehigh, Iowa. 
Plates.

XXX. Reel cutting table for hollow ware, Lehigh Brick and Tile Company, Lehigh, Iowa.

XXXI. (a) Dry press shape machine. (b) Method of facing dry press brick in a round, down draft kiln, Corey Pressed Brick and Coal Company, Lehigh, Iowa.

XXXII. Pit of the Campbell Brick and Tile Company, Lehigh, Iowa.

XXXIII. Pit of the Sioux City Brick and Tile Company, North Riverside, Sioux City, lowa.

XXXIV. Plant of the Sioux City Brick and Tile Company, North Riverside, Sioux City, Iowa.

$\mathrm{XXXV}$. Interior view of Haigh continuous kiln, showing method of setting hollow ware, Sioux City Brick and Tile Company, Sioux City, Iowa.

XXXVI. Plant near Moravia, Iowa, showing method of manufacturing surface clays.

XXXVII. Clay pit of the Kelly Brick and Tile Works.

XXXVIII. Plate showing comparative results of freezing tests on brick and stone.

FIGURES.

1. Fairbanks machine used in measuring the tensile strength of clays.

2. The Seger Volumeter.

3. Hoskins furnace with Le Chatelier's pyrometer for making fusibility tests on clays.

4. Automatic clay gatherer, adapted to yards using surface clays.

5. Side-dumping clay car.

6. End-dumping clay car.

7. Sectional view of the jaw type of rock crusher.

8. Clay crusher, corrugated rolls type.

9. Clay crusher, corrugated rolls with automatic relief feeder.

10. Clay disintegrator and pulverizer of the Steadman type.

11. Williams disintegrator and pulverizer.

12. Rotary type of clay screen.

13. Type of revolving clay screen with automatic brush cleaner.

14. Soaking pit and wooden pug mill. Carl Hagemeister, Muscatine. Iowa.

15. Common brick mold for soft mud brick.

16. Ring Pit. Carl Hagemeister, Muscatine, Iowa.

17. Horizontal type of soft mud brick machine.

18. Horzontal type of soft mud brick machine.

19. Vertical type of stiff mud brick and tile machine.

20. The automatic indenting brick cutter.

21. Sectional views of Reciprocating Oscillating side cut table.

22. Modern four-mold dry press.

23. Open air drying, Samuels brickyard, Muscatine, Iowa. 
FIGURES.

24. Cast iron flat car with pallets.

25. Double deck steel car.

26. Combination transfer car and turntable.

27. Floor plan, Multiple stack, round down draft kiln.

28. Round down draft kiln with two stacks.

29. Rectangular down draft kiln with stacks at the ends.

30. Interior of rectangular down draft kiln showing method of facing dry pressed brick.

31. Boiler with dome shell extended for full front. Wrought iron hangers.

32. Domeless boiler with nozzles. Shell extended for full front.

33. A good type of rocking grate.

34. Type of boiler feed pump; Duplex.

35. Duplex pump in section.

36. Feed-water heater.

37. Feed-water heater in section.

38. Type of open feed-water heater.

39. Sectional view of open feed-water heater.

40. Type of closed feed-water heater.

41. Section near Edgewood, showing over sixty feet of Maquoketa shales.

42. Maquoketa shales west of Graf.

43. Characteristic topography of the Maquoketa shales, near Graf.

44. Plant of American Brick and Tile Company.

45. Plant of the Granite Brick Company.

46. Pit of the Boone Clay Works.

47. Plant of the Boone Clay Works.

48. Plant of the Platt Pressed and Fire Brick Company, Van Meter, Iowa.

49. Plant of Webster City Brick and Tile Company.

50. Honestone Quarries showing Coal Measure shales, on the Iowa river, west of Iowa Falls.

51. Raney Brothers Brick and Tile Plant.

52. Pit of the Iowa Brick Company, Des Moines, Iowa.

53. A portion of the plant of the Iowa Brick Company.

54. Represses used by the old Iowa Brick Plant, Des Moines, Iowa.

55. Pit of the Merrill Brick Company, Des Moines, Iowa.

56. A portion of the plant of the Merrill Brick Company, Des Moines, Iowa.

57. Clay pit of the Davenport Brick and Paving Company, Buffalo, Iowa.

58. Plant of the Davenport Brick and Paving Company, Buffalo, Iowa.

59. Plant of the Le Claire Brick and Tile Company, Island City, Iowa.

60. Pit of the Ottumwa Brick and Construction Company, Ottumwa, Iowa.

61. Compartment continuous kiln, modified “'Dunn” pattern, Ottumwa Brick and Construction Company, Ottumwa, Iowa.

62. Modified Dunn continuous kiln in process of construction, Ottumwa Brick and Construction Company, Ottumwa, Iowa.

63. Two of the Fort Dodge brick plants-Fort Dodge Brick and Tile Company and the Fort Dodge Clay Works. 
FIGURES.

64. A portion of the plant of the Fort Dodge Stoneware Company, Fort Dodge, Iowa.

65. Plant of the Kalo Brick and Tile Company, Kalo, Iowa.

66. Boyd four mold, dry press machine.

67. Plant of the Campbell Brick and Tile Company, Lehigh, Iowa.

68. Clay shales with concretions of clay-ironstone, Pottawattamie county, Iowa.

69. Benton shales exposed in railroad cut three miles south of Hawarden, in Sioux county, Iowa.

70. Pit of Holman and Brother Brick Plant, Sargents Bluff, Iowa.

71. Interior view of machinery building, Holman and Brother Brick Plant, Sargents Bluff, Iowa.

72. Interior view of Haigh continuous kiln showing method of setting brick.

73. Top view of Haigh continuous kiln showing arrangement of fire holes and open court.

74. Pit of the Muscatine Pressed Brick Company.

75. Brick machine used in the manufacture of soft mud brick.

76. Machine used by the Davy Burnt Clay Ballast Company.

77. Coaling machine used by the Davy Burnt Clay Ballast Company.

78. Stratified loess in clay pit of Seig \& Size.

79. Loess occurring over stratified drift in the pit of the Le Mars Brick and Tile Company.

80. Pit of C. B. Bently and Sons, near Tama, Iowa.

81. Plant of Gethmann Brothers Pressed Brick Company.

82. Diagram showing results of compression tests.

83. Diagram showing results of transverse tests.

84. Diagram showing results of absorption tests.

85. Diagram showing per cent of absorption of brick tested.

86. Diagram showing results of freezing tests.

87. Diagram showing comparative loss on a varying number of freezings.

88. Diagram showing results of transverse and freezing tests.

89. Diagram showing comparative results of the different tests.

90. Transverse tests, Council Bluffs brick.

91. 'Transverse tests, Webster City brick.

92. Transverse tests, Des Moines brick.

93. Transverse tests, Mason City Brick.

94. Absorption tests, Council Bluffs brick.

95. Absorption tests, Webster City brick.

96. Absorption tests, Grand Junction brick.

97. Absorption tests, Des Moines brick.

98. Absorption tests, Mason City brick.

99. Absorption tests, Kelly brick.

100. Absorption tests, Ames hand made brick.

101. Comprehensive diagram of results of tests on Council Bluffs brick.

102. Results of tests, Webster City brick. 


\section{FIGURES,}

103. Freezing tests, Goodwin brick.

104. Comprehensive diagram, Grand Junction brick.

105. Comprehensive diagram, Mason City brick.

106. Comprehensive diagram, Council Bluffs brick.

107. Comprehensive diagram, Webster City brick .

108. Comprehensive diagram, Goodwin brick.

109. Comprehensive diagram, Grand Junction brick.

110. Results of tests, Kelly brick.

111. Results of tests, Ames hand made brick.

112. Diagram showing comparative results of tests.

113. Diagram of comparative results.

114. Diagram of comparative results .

115. Crushing tests, Boone brick .

116. Crushing tests, Burlington brick.

117. Crushing tests, Capital City brick.

118. Crushing tests, Flint brick.

119. Crushing tests, Iowa brick.

120. Crushing tests, Merrill brick.

121. Transverse tests, Boone brick.

122. Transverse tests, Burlington brick.

123. Transverse tests, Capital City brick.

124. Transverse tests, Flint brick.

125. Transverse tests, Iowa brick.

126. Transverse tests, Merrill brick.

127. Rattler and absorption tests, Boone brick.

128. Rattler and absorption tests, Burlington brick.

129. Rattler and absorption tests, Capital City brick.

130. Rattler and absorption tests, Flint brick.

131. Rattler and absorption tests, Iowa brick.

132. Rattler and absorption tests, Merrill brick. 
